\title{
Self-Regulatory Organizations in Russia and European Countries: Current State and Prospects of Development
}

\author{
${ }^{* 1}$ Lilia A. Sungatullina, Andrey V. ${ }^{2}$ Mikhaylov, ${ }^{3}$ Aygul V. Valeeva, ${ }^{4}$ Anna I. Kovshova \\ 1, 2, 3, ${ }_{4}$ Kazan Federal University, Faculty of Law, \\ Email: lilia.sungatullina@mail.ru, Contact: +7(905) 3118576
}

\section{Received: $21^{\text {st }}$ October 2017 Accepted: $16^{\text {th }}$ November 2017, Published: $31^{\text {st }}$ December 2017}

\begin{abstract}
This paper presents the legal nature of self-regulation, the legal status and functions of self-regulating organizations, notes the advantages of self-regulation before state regulation and control. The problems of development of self-regulation, the influence of historical features of the development of countries on the current state of self-regulation are considered. The experience of development and the current state of selfregulation in Russia and in European countries are analyzed. Features of functioning of self-regulating organizations uniting SROs of different countries are described. Separate features characteristic to selfregulation in individual spheres of entrepreneurial activity and the most striking features of self-regulating organizations of individual European countries are specified. The authors consider the current state of the legislation on self-regulation in Russia and the prospects for its improvement. There are identified features of the functioning of self-regulating organizations in the Russian Federation; differences in the development of self-regulation in Russia and the EU are revealed. At the same time, the research conducted allows us to draw a conclusion about common goals, trends, problems and directions of development of self-regulation in Russia and European countries. The authors come to the conclusion that it is necessary to further improve the legislation on selfregulation in Russia, as well as on the need for further study and adoption of positive European experience in the development and functioning of self-regulating organizations.
\end{abstract}

Keywords: Self-regulation, Efficiency, Legislation, Improvement, Legal Regulation, Codes of Ethics.

\section{Introduction}

Effective conduct of economic policy is one of the most important tasks of any state. In many respects, the effectiveness of the economy depends on the properly chosen and adequate legal regulation. For some spheres of the economy, state control and administrative measures of influence are preferable. Other spheres are more successful when the market entities are given with the opportunity to independently establish business standards. The search for a balance between the state impact and the provision of opportunities for entrepreneurs to establish their own rules of doing business has led to the emergence of self-regulation and self-regulating organizations.

\section{Methods}

The methodological basis of the research involved such general scientific methods of cognition as analysis, synthesis, system research method, as well as particular-scientific methods: comparative law, historical, formal-legal, legal research intersectoral method, legal modeling method, etc. An interdisciplinary research method was also used.

\section{Results and Discussion}

In a broad sense, self-regulation can be understood as allowing entities to independently determine the conditions and rules for their activities. The subjects of professional and entrepreneurial activity are often able to independently realize their legal personality in order to satisfy not only their personal needs, but also to protect the interests of the state and society.

In the narrow sense, self-regulation is the activity of self-regulating organizations (SROs).At the same time, self-regulation in a narrow sense is characterized by the same tendencies and interdependencies as for selfregulation in the broad sense.

The modern history of self-regulation in Europe has duration of several decades, the prototype of selfregulating organizations were medieval handicraft shops. In the 1950s, when the post-war economies of European countries began to enter a stage of gradual growth, professional communities of various spheres proclaimed that they would participate in the most active way in the formation of a new market. This initiative was supported by state bodies. Foreign experts have come to the conclusion that no one can form the most honest conditions for the development of the market better than a professional community.

The main objectives of the self-regulation idea development were the development of fair competition and the fight against corruption. Today, the selfregulation system in Europe extends to various sectors of the economy: from the construction industry to advertising services.

Self-regulation exists in most member states of the European Union. In some countries, self-regulation is regulated by law in such detail that its scope is very limited. In other countries, where the legislative consolidation is not so detailed, regulation is effectively carried out by self-regulating organizations. But the positive role of self-regulation is recognized in all EU countries without exception. 
An interesting example of the development of selfregulation is the UK which policy in this area has its own distinct specific features. The state takes an active part in the development of voluntary codes of selfregulating organizations. These codes are a system of formal rules that guide all members of a SRO. Advantages of such codes are the ability to encourage business representatives to use their rules in their work activities, and to ensure appropriate behavior in the market.

Companies that do not participate in voluntary agreements are under more stringent control of the state for unfair conduct. At the same time, most of the functions on monitoring the implementation of codes lie directly in self-regulating organizations, which also have the right to monitor compliance with stateapproved codes.

For example, a health care system in the UK is built on the basis of the self-regulation principles. Here, in total, there are 13 self-regulating organizations that were related to medicine, all of them were organized according to a functional feature (for example, a separate organization for physiotherapists, a separate organization for midwives and nurses, etc.). The General Medical Council is the largest SRO in the UK; it occupies a key position in the British healthcare system, and unites about 200,000 practicing physicians. Membership in it is not mandatory, but all practitioners are required to register, the Council maintains a register of UK doctors. Despite this, about 10 percent of British doctors decided not to be a part of the General Medical Council. This is permissible from the legal point of view, but such specialists face difficulties related to the strength of tradition and the cultural characteristics of Great Britain. Demand for the services of such doctors is usually lower, as well as the level of their incomes.

In the countries of Eastern Europe, which have relatively recently joined the EU, the development of self-regulation stalled after the Second World War. Most of the SROs here ceased to exist in the period of socialism. After 1989, the process of rapid recovery of activities of self-regulatory organizations began.

There are distinctive features characteristic to selfregulation of individual countries. So, for example, self-regulating organizations in Poland are characterized by a pronounced regional character ${ }^{1}$.Regional chambers as collective members are part of the nationwide self-regulating organizations. Most of these organizations have the status of organizations with mandatory membership. Funding comes at the expense of membership fees and various

\footnotetext{
${ }^{1}$ See more: Snyder F. Soft Law and the Institutional

Practice in the European Community // The

Construction of Europe. Essays in Honor of Emile

Noel / Ed. By M. Stephen. - Dordrecht; Boston;

London, 2010. - 198 p.
}

fees for the issuance of certificates, licenses and other documents, as well as through tuition fees (for example, for refresher courses). Almost all SROs compose and approve their ethical codes and norms which all members of the society must be guided in their professional activities. Often these norms operate in parallel with existing pan-European or international standards. It is impossible to imagine modern Poland without professional organizations, where SROs occupy an important place in the economy, healthcare, law, agriculture and other spheres.

There are self-regulatory organizations at the EU level, which unite the SROs of individual countries.

Bright examples of the activities of such a selfregulating organization can be the work of the European Construction Association (CECE). This association includes 1200 companies (120 thousand employees) from 12 countries. The task of the organization is to unite producers of building materials, promote their economic interests, resolve technical issues and standardization problems, and collect statistical data.

CECE is a recognized organization that promotes the development of organizations of construction equipment and related business sectors. CECE serves to formation of a fair competitive environment by uniting and coordinating the actions of organizations around the world.

One of the most favorable spheres for the introduction of self-regulation is advertising. In most European countries, the advertising market is regulated by SROs. The basis of any such self-regulation system is the Code of Advertising Practice of the International Chamber of Commerce (ICC). It established the basic principles: advertising should be legal, orderly, honest, truthful, and respect the principles of social responsibility.

The activities of European SROs in the field of advertising can be demonstrated using the example of EASA (Alliance of European Advertising Standards). EASA promotes the development of high ethical standards through effective self-regulation to the benefit of consumers and business. Self-regulating organizations - members of EASA are represented in many EU countries. In Slovakia, for example, such an organization is Rada pre reklamu (RPR), the Slovak Advertising Standards Council. The main goal of the Council is to codify and update the established ethical principles of advertising practice in Slovakia, the application of these principles in society, and monitoring of ethics in advertising.

It is also necessary to note the activities of such SROs as the Interactive Advertising Bureaux (IAB Europe). IAB brings together the National Bureaus of Interactive Advertising (IABs) across Europe. Providing support to the main media groups, 
advertisers, agencies, portals, providers of technologies and services, IABs represent the interests of more than 5,500 member companies. IAB Europe coordinates the activities of organizations throughout the sector, including public affairs, comparative analysis, research, standard setting and improvement of activities. This organization is represented in the Russian Federation.

In Russia, self-regulating organizations in the modern sense have become widespread recently, despite the fact that self-regulation in our country also has a fairly rich history.The tendencies, patterns and goals of the development of self-regulation in Russia do not differ from European countries.

Self-regulating organizations in the securities market can be considered as the first modern SROs in Russia. So, in 1994 the Professional Association of Stock Market Participants (PAUFOR) was established, which became the prototype of the future self-regulating organization, the National Association of Stock Market Participants (NAUFOR). This marked the beginning of a rapid process of creating SROs in various areas of entrepreneurial and professional activity.

In Russia, it is extremely important to protect the interests of business, primarily in relations with the state. Normative acts restricting the rights of entrepreneurs are often adopted. Individual organizations for various reasons are not always able and ready to argue with the state; associations of entrepreneurs do it much easier. Therefore, one of the goals of self-regulation is to represent and protect the interests of the business community in relations with government bodies.

In Russia, the legal regime of SROs is enshrined in the federal law No. 315-FZ "On Self-Regulating Organizations" (hereinafter - the Federal Law on SROs). In many branches, in addition to the general law on SROs, special norms on self-regulation operate.

A self-regulatory organization in Russian legislation is defined as a non-profit organization established for the purpose of self-regulation based on membership and integrating business entities based on the unity of the industry producing goods (works, services) or uniting the professional actors of a certain type.

The law imposes certain requirements on a non-profit organization that intends to acquire the status of a SRO. This is a certain number of members, the existence of standards and rules of entrepreneurial or professional activity mandatory to perform for all members of the self-regulatory organization, provision by the self-regulatory organization with additional property responsibility of each of its members to consumers of manufactured goods (works, services) and other persons.
In the Russian Federation, membership in selfregulating organizations is voluntary. However, there is a rule according to which federal law can define an exception to the principle of voluntary entry into a SRO when, taking into account the public significance of certain activities, the state requires these entities to have compulsory membership in a self-regulating organization, considering such participation as an essential condition for ensuring the quality of services provided.

So, participation in a self-regulatory organization is a prerequisite for carrying out the activities of arbitration managers, appraisers, builders, auditors, and others. Such activities can only be carried out by members of a SRO. A vivid example of creating a voluntary selfregulatory organization is the SRO in the field of advertising.

Self-regulating organizations have the right to create unions (associations) of SROs. For example, the SROs specialized in construction have created NOSTROY, the National Association of Builders, which is a non-governmental non-profit organization that unites self-regulating organizations on the basis of mandatory membership. The objectives of this organization's activity are observance of public interests of construction SROs, representation and protection of SROs in government bodies, interaction between SROs and these bodies and consumers.

Self-regulation in Russia has some technical problems, such as the contradictory attitude of SRO participants to the compensation fund, the creation of unscrupulous SROs, the insufficient consolidation of issues related to the judicial protection of SRO members, and others. However, the development of self-regulation, including the overcoming of legal and technical problems, proceeds quite rapidly.

\section{Summary}

Thus, the SRO institution in Europe, having long settled the issues of a technical nature (the conditions of membership and admission to the market, the amount of mandatory contributions, liability insurance, etc.), today forms ethical norms of doing business, linking them with those norms of morality and ethic that exist in the Europian society. At the same time, controversial situations arising in this or that sphere do not always require intervention of courts and representatives of ministries and departments into the process.

Despite the fact that self-regulating organizations continue to develop successfully on the European continent in general, in the EU countries in particular, one must recognize the existence of a number of problems in this area, for example, the issue of private and public responsibility of SRO participants in European countries was not ultimately resolved until now. Currently, in Europe there is a process of searching for the most effective model of private and 
public regulation, and the idea of creating such a regulatory strategy as co-regulating gains a popularity, when state authorities participate in the selection and definition of goals for private companies.

Russia needs to take into account and adopt the European experience of self-regulation to establish an effective and independent system of self-regulating organizations, to continue developing this sphere and to monitor the effectiveness of the SRO.

\section{Conclusions}

As a whole, for today self-regulation is the most perfect system of management of economy branches. Self-regulation is much more fair and productive, rather than pressure on business from above on the part of power structures.

In order for the world to become better, constructive social activity is needed, to which professional selfregulation in various spheres of the economy can be fully applied.

\section{Acknowledgments}

The work is carried out according to the Russian Government Program of Competitive Growth of Kazan Federal University.

\section{References}

[1] Mikhailov A.V. Efficiency of the business law norms // Proceedings of Kazan University, 2014.Vol. 156. P. 86-96.

[2] Petrov D.A. Legal status of a self-regulatory organization in the field of entrepreneurship: problems of theory and practice: Monograph. SPb.: NestorHistory, 2015. - 320 p.

[3] Russian Business Law: Textbook / L.V. Andreeva, T.A. Andronova, N.G. Apresova and others; executive editors I.V. Ershova, G.D. Otnyukova. - 4th edition. Moscow: Prospekt, 2012. - 816p.

[4] Sungatullina L.A. Participation of subjects of entrepreneurial and professional activity in selfregulating organizations: civil research: thesis for the degree of Candidate of Juridical Sciences, Kazan, 2016.229 p.

[5] Frankel, Tammar. Self-regulation of insider-trading in mutual funds and advisers // Brooklyn Journal of Corporate, Financial and Commercial Law. - 2013. Vol.8 Issue 1. - P. 80-91.

[6] Henderson, M. Todd. Self-Regulation for the Mortgage Industry// University of Chicago Legal Forum. - 2013. - P. 229-269.

[7] Self-Regulation. Mapping Exercise Report Linda Wilks, Ross Gordon, Douglas Eadie and Susan MacAskill, Institute for Social Marketing, The Open University \& University of Stirling// July 2009 Prepared for the European Commission DG SANCO. 40p.

[8] Self-regulation in European Contract Law / FABRIZIO CAFAGGI// EUI Working Paper LAW No. $2006 / 43$
[9] Snyder F. Soft Law and the Institutional Practice in the European Community // The Construction of Europe. Essays in Honour of Emile Noel / Ed. By M. Stephen. - Dordrecht; Boston; London, 2010. - 198 p. [10] SOFT LAW, SELF-REGULATION AND COREGULATION IN EUROPEAN LAW: Where Do They Meet? Linda Senden, The author is Professor of European Law, Faculty of Law, Tilburg University, the Netherlands// Electronic Journal of Comparative Law, vol. 9.1 (January 2005), http://www.ejcl.org/. 